\title{
THE CONSTITUTION OF BANGLADESH AND A SHORT CONSTITUTIONAL HISTORY
}

\author{
By S. C. SEN
}

\section{The Birth of Bangladesh and Preconstitution Documents}

East Bengal (now Bangladesh) was always an uneasy partner in a hasty marriage. In the euphoria created during a somewhat panicky withdrawal of the British from Indian empire, it suddenly found itself as a part of a new State called Pakistan. Separated by over 1200 miles of Indian territory from its other wing it became a junior and neglected partner of a troubled new nation. Linguistically, culturally and anthropologically different from the members of the other part of Pakistan its people constituted majority in number but minority in influence. Speaking a language called Bengali - an extremely rich language in which the great Poet Rabindranath Tagore had already received a Nobel award - it found that even its linguistic rights were being denied. The majority of people in the then Pakistan spoke Bengali as Bengali was the mother tongue of all the people in East Bengal, but the pride of place was given to Urdu, a language not even understood in East Bengal. It was a standing complaint that economically East Bengal was discriminated against by the Government of Pakistan; that although it produced all the jute and the tea which were the main foreign currency earner, very little of the foreign currency was utilised in East Bengal; that recruitment to the armed forces and civil services was heavily against East Bengal and that the economy was going from bad to worse. Even Yahya Khan the then President of Pakistan on November 8, 1971 stated "no one ever treated the Bengalees fairly ... East Pakistan was down and out and we did not pay sufficient attention to its development". A common religion was the only link between East Bengal and West Pakistan.

The people of East Bengal were too proud not to resist it or to take it lying down. But democratic methods of expression of protest were not available to them for very long. In 1958 martial law was clamped down on the whole of Pakistan including East Bengal and the country was since then under the management and domination of one military ruler after another.

The spearhead of the movement of independence of East Bengal was a tall and handsome Bengalee called Sheikh Mujibur Rehman, affectionately called Bangabandhu (Friend of Bengal) by his people. A live-wire and pleasant personality even as a student he was deeply involved in politics and absolutely fearless. In March 21, 1948 Mohamed Ali Jinnah, the founder of Pakistan, declared at a meeting in Dacca "that Urdu is going to be the lingua franca of this country. Anyone who says anything else is an enemy of Pakistan". No sooner had he said this than a small group of students led by Mujibur Rehman protested. They wanted Bengali language to be given its rightful place and were not going to be bulldozed into accepting Urdu. They were promptly sent to jail. Jail visit had become a regular part later of the life of Mujibur Rehman. While in jail Mujibur Rehman was elected a Joint Secretary of the Awami League, the party which ultimately won in the national elections in 1954. Mujib had a short spell 
as a member of a Ministry. In 1956 when the new Constitution of Pakistan was proclaimed Mujibur Rehman along with other Awami League leaders rejected it as "a halfway provincial autonomy" and continued their campaign for total autonomy as well as the abolition of economic and financial discrimination between the two wings of Pakistan. On October 8, 1958 a military coup d' etat under Ayub Khan took place in Pakistan as a result of which the 1956 Constitution was abrogated and the central and provincial governments dissolved. Mujibur Rehman was arrested and detained without trial for over a year. The authorities launched half a dozen criminal cases against him but the charges failed and he was released in December 1959. In 1962 Mujib was again imprisoned for leading the agitation against the imposition of the 1962 Constitution introduced by President Ayub Khan. He was again released after some time. In 1966 when the Government of Pakistan lifted some restrictions on political activity Mujibur Rehman announced a six-point programme in achieving full regional autonomy for East Bengal and his party started mobilising public opinion for attainment of this objective. Promptly he was arrested again by the military rulers and was later implicated in what was known as the notorious Agartala Conspiracy case and charged with treason. The prosecution failed and he was released in January 1969. The agitation led by Mujib was primarily responsible for toppling General Ayub Khan in March 1969.

General Yahya Khan replaced Ayub Khan. He pledged that he would hand over power to elected representatives of the people after holding general elections. Mujib and his party contested the elections on the basis of the six-point formula of the Awami party.

\section{The Six-point Formula}

The six-point programme put forward by the Awami League was also the Party's election manifesto.

(1) A federal form of Government would be established.

(2) The Federal Government would control only defence and foreign policy, all other subjects being vested in the federating States.

(3) Two separate, freely convertible currencies would be introduced for East and West Pakistan, or if a single currency was maintained, constitutional provision would be made to stop the flight of the capital from East to West Pakistan. There would be a separate banking reserve and separate fiscal and monetary policy for East Pakistan.

(4) The States would have exclusive authority to levy taxes, federal expenses being met from a uniform percentage of all State taxes.

(5) Separate external trade accounts would be maintained for each of the States, and foreign exchange earned from external trade would be at their disposal. Federal foreign exchange requirements would be met by the States on the basis of an equal percentage rate. Indigenous commodities would move between the States, free of taxation or tariffs. The States would be allowed to maintain trade representatives abroad and to negotiate trade agreements with other countries. 
(6) A militia or paramilitary force, an ordnance factory, a military academy and the Naval headquarters would be set up in East Pakistan.

In December 1970 the general elections were held on the basis of the one-man one-vote franchise, the first ever such election in Pakistan. Mujibur Rehman and his party scored a sweeping victory. Out of 300 seats in the provincial assembly of East Bengal it captured 288 seats. Out of 313 seats in the national assembly it captured 167 seats. Victory of Mujibur Rehman in East Bengal was complete and he was entitled to become the Prime Minister of the whole of Pakistan as a result of his majority in the national assembly, a fact which was not acceptable to some powerful persons and politicians in West Pakistan.

Events now began to happen at dramatic speed. The national assembly session was delayed from time to time by President Yahya Khan. People of East Bengal were not prepared to wait ad infinitum. Tempers of the people began rising high. The postponed meeting of the national assembly was fixed on the 3rd of March 1971. On the 1st of March 1971 the news reached Dacca that President Yahya Khan had again postponed the meeting of national assembly. There were violent demonstrations in Dacca against this postponement. Mujibur Rehman described the postponement of the national assembly as a direct conspiracy and launched a peaceful non-cooperation movement throughout East Bengal. $\mathrm{He}$ said "if the conspirators still think they can perpetuate their colonial rule they are living in a fool's paradise... They will see history made if the conspirators fail to come to their senses." The students of Dacca University spearheaded a movement against continuance of martial law and massive demonstrations were held in the University and other educational institutions in Dacca. The cry of Free Bengal and Freedom for Bangladesh was now the cry all over East Bengal. By mid-night of the 1st of March Dacca was cut off from the outside world when postal, telegraph, telephone and airport employees walked out.

On the 2nd of March Mujibur Rehman announced a province-wide peaceful hartal from March 3rd to 6th to press people's demand for transfer of power. Military Governors replied by more shooting. Addressing a public meeting on the 3rd March Mujibur Rehman instructed his people not to pay taxes unless and until the power was transferred. He called for total immobilisation of the Government and of the system and called for closure of Government offices, industries and commercial establishments and markets. He also demanded return of the troops to their barracks and complete stoppage of all activities by troops.

On the 6th of March President Yahya Khan promised in a broadcast that the inaugural session of the National Assembly would take place on the 25th of March. Simultaneously, some leaders in West Pakistan made it known that they will not join the National Assembly. Mujibur Rehman also stated that he had requested Yahya Khan to convene the National Assembly by the 15th of February, but Yahya Khan had refused to do that and had acted according to the dictates of minority leaders from West Pakistan. Mujibur Rehman was not consulted at all and he was not willing to act any more on the basis of the statements of President Yahya Khan. On the 7th of March Mujibur Rehman gave his historic speech at the Ramna Race Course in Dacca. Extracts from this speech are set out below: 


\section{The Race Course Speech of Mujibur Rehman}

"I am before you today with a very heavy heart. You know and understand everything. We have done our best, and yet the streets of Dacca, Chittagong, Khulna, Rangpur and Jessore are drenched with the blood of my brothers.

Today the people of Bengal want freedom; they want to live; they want their rights restored.

You elected Awami League to frame the constitution. We hoped that the National Assembly would sit and we would frame the constitution. Through this constitution, the people would achieve their economic, political and cultural freedom. The history of the last 23 years is the history of the agonised cry of the people of Bengal, it is a painful history of giving blood, it is the history of the tears of an oppressed people.

We gave blood in 1952. In 1954, even though we won the election, we were denied the opportunity to rule. By promulgating Martial Law in 1958, Ayub Khan kept us in bondage for ten years.

In 1966, the six-point formula was submitted before the nation and for this many of my brothers were murdered. In 1969, in face of the mass movement, Ayub fell and Yahya came. Yahya said he would hand over power to the people and there would be a constitution. We accepted his promise. You all know what happened after that.

But what did we get? Arms have been used against the unarmed people of Bengal. They have no weapons. The arms we bought at our own cost to defend the country from external aggression, are being used to kill my innocent people. The suffering people are the targets of bullets.

Whenever, we Bengalees, the majority of the nation, sought power to exercise our right to rule, a conspiracy was immediately hatched to stop it. They unleashed repression on us.

Our struggle from now on is a struggle for emancipation for freedom. Blood-stains of those killed have not yet dried and I cannot step on the blood of the martyrs to attend the National Assembly on March 25.

Yahya Khan has convened the Assembly. But my demands are: Lift Martial Law; take the soldiers back to the barracks; investigate the mass killings; and transfer power to the elected representatives. After these, we will consider whether we could sit in the National Assembly or not. Before these demands are fulfilled there is no question of our sitting in the Assembly ...

There is a plot to finish off the people of Bangladesh. So please be careful ... If they fire one single bullet, turn every home in Bengal into a fortress. You will have to face the enemy with whatever you have. We must make him die of thirst and hunger, if necessary. The roads and ferries will have to be closed down. If I am not there to give you directions or if none of my colleagues is there for this purpose, you would continue yourselves.

To the soldiers of the Pakistan Army I say this: You are my brothers, if you stay in the barracks, you will be left alone, but if you come to murder us, the consequences will be bad. You will not be able to suppress seventyfive million people any more. Bengalees have learnt how to face death ... nobody can suppress them ...

$\mathrm{Be}$ on your guard. You should remember that the enemy has infiltrated 
among us. They would try to create dissension among us under cover. Bengalees, non-Bengalees, Hindus and Muslims are all our brothers. It is our responsibility to protect them all...

There is still a possibility of our living like brothers with the people of West Pakistan, if there is a peaceful settlement. Otherwise there is none. If the Pakistan Army commits any more excesses we may never look at one another's face again...

Be ready with whatever weapons you have in your hands. Since we have given blood once we will give more, but Bengal must be liberated ... This is a struggle for survival, for emancipation and for freedom ...

\section{The Declaration of Independence}

Whole of East Bengal was now virtually under Mujibur Rehman. Civil life had come to a dead halt. There was however great expectancy as to what was going to happen on the 25th of March 1971 when the National Assembly was to meet according to the President's declaration. Mujibur Rehman had however put four conditions for participating in the National Assembly deliberations. He asked for immediate end of Martial Law regime, withdrawal of troops from East Bengal, enquiry into killings of strikers and immediate handing over of the power to the people's representatives. When 25th of March arrived the situation had totally changed. It appeared that President Yahya Khan had already flown back to Rawalpindi and also had flown back the leaders of West Pakistan parties who had come to Dacca. Instead, large numbers of West Pakistani troops had arrived and the army let loose a reign of terror and repression. On the night of the 25th of March 1971 Mujibur Rehman declared that a sovereign independent People's Republic of Bangladesh had come into existence. This was a declaration of total independence. On the 26th of March 1971 Mujibur Rehman was arrested and flown to an unknown destination in West Pakistan. The war of independence of the people of Bangladesh started in right earnest and in full fury. It is not within the scope of this article to give any description of the war of independence of Bangladesh but certain important features of constitutional importance are noted below.

\section{Proclamation of the Republic of Bangladesh}

On the 17th of April 1971 the Democratic Republic of Bangladesh was proclaimed as a formally constituted State to be run by a presidential form of Government. The Republic was proclaimed by its Vice-President Nazrul Islam as President Mujibur Rehman was in prison. Those present at the ceremony included Prime Minister Tazuddin Ahmed, members of his Cabinet and a large number of reporters and photographers from many countries. The declaration of independence and establishment of provisional Government of Bangladesh Republic was in the following terms:

On April 10, 1971, the Provisional Government of Bangladesh in a meeting at Mujibnagar proclaimed independence by issuing the following declaration:

"Whereas free elections were held in Bangladesh from December 7, 1970 to 
January 17, 1971, to elect representatives for the purpose of framing a constitution;

And whereas at these elections the people of Bangladesh elected 167 out of 169 representatives belonging to the Awami League;

And whereas the assembly so summoned was arbitrarily and illegally postponed for indefinite period;

And whereas General Yahya Khan summoned the elected representatives of the people to meet on March 3, 1971, for the purpose of framing a constitution;

And whereas instead of fulfilling their promise and while still conferring with the representatives of the people of Bangladesh, Pakistan authorities declared an unjust and treacherous war;

Whereas in the facts and circumstances of such treacherous conduct, Bangabandhu Sheikh Mujibur Rehman, the undisputed leader of 75 million of people of Bangladesh, in due fulfilment of the legitimate right of self-determination of the people of Bangladesh, duly made a declaration of independence at Dacca on March 26, 1971, and urged the people of Bangladesh to defend the honour and integrity of Bangladesh;

And whereas in the conduct of a ruthless and savage war the Pakistani authorities committed and are still continuously committing numerous acts of genocide and unprecedented tortures, among others on the civilian and unarmed people of Bangladesh;

And whereas the Pakistan Government by levying an unjust war and committing genocide and by other repressive measures made it impossible for the elected representatives of the people of Bangladesh to meet and frame a constitution, and give to themselves a government;

And whereas the people of Bangladesh by their heroism, bravery and revolutionary fervour have established effective control over the territories of Bangladesh;

We, the elected representatives of the people of Bangladesh, as honour bound by the mandate given to us by the people of Bangladesh whose will is supreme, duly constituted ourselves into a constituent assembly and having held mutual consultations;

And in order to ensure for the people of Bangladesh equality, human dignity and social justice, declare and constitute Bangladesh to be sovereign people's republic and thereby confirm the declaration of independence already made by Bangabandhu Sheikh Mujibur Rehman;

And do hereby affirm and resolve that till such time as a constitution is framed Bangabandhu Sheikh Mujibur Rehman shall be the President of the Republic and that Syed Nazrul Islam shall be the Vice-President of the Republic;

And that the President shall be the Supreme Commander of all the armed forces of the Republic, shall exercise all the executive and legislative powers of the republic including the power to grant pardon, shall have the power to levy taxes and expend monies, shall have the power to summon and adjourn the constituent assembly;

And do all other things that may be necessary to give to the people of Bangladesh an orderly and just government; we, the elected representatives 
of the people of Bangladesh do further resolve that in the event of there being no President or the President being unable to enter upon his office, or being unable to exercise his powers and duties due to any reason whatsoever, the Vice-President shall have and exercise all the powers, duties and responsibilities, herein conferred on the President.

We further resolve that we undertake to observe and give effect to all duties and obligations devolved upon us as a member of the family of nations and by the Charter of the United Nations.

We further resolve that this proclamation of independence shall be deemed to have come into effect from March 26, 1971.

We further resolve that in order to give effect to this instrument we appoint Prof. M. Yusuf Ali our duly constituted potentiary and to give President and the Vice-President oaths of office."

The war of independence of Bangladesh went on with mad fury. On the 3rd of December 1971 the dimensions were aggravated by Pakistan's declaration of war on India. The war however was of a short duration and on the 16th of December 1971 the Commander-in-Chief of the Pakistani Army in Bangladesh surrendered to the Commander-in-Chief of the Indian Army in Bangladesh. Mujibur Rehman however was still rotting in a jail in West Pakistan. On the 8th of January 1972 Mujibur Rehman was released from prison. He was flown to London wherefrom he arrived in Dacca via Delhi and was accorded a tumultous welcome by his people. Mujib promptly sat down to set his house in order and to formalise the constitutional documents of Bangladesh. On the 11th of January 1972 Mujibur Rehman issued the following provisional Constitution Order:

\section{The Provisional Constitution Order}

The Provisional Constitution of Bangladesh Order, 1972, promulgated by Sheikh Mujibur Rehman, envisages a Parliamentary democracy in the country. A Bangladesh Gazette Extraordinary notification dated January 11, said, the nation's Bangladesh Constituent Assembly would consist of representatives of the people of Bangladesh returned to the National and Provincial Assembly seats in the elections held in December 1970, January 1971, and March 1971, "not otherwise disqualified by or under any law".

The main points of the order were: (a) There shall be a Cabinet of Ministers with the Prime Minister as the Head, (b) The President shall, in exercise of all his functions, act in accordance with the advice of the Prime Minister, (c) The President shall commission as Prime Minister a member of the Constituent Assembly who commands the confidence of the majority of the members of the Constituent Assembly. All other Ministers, Ministers of State and Deputy Ministers shall be appointed by the President on the advice of the Prime Minister, (d) In the event of a vacancy occurring in the office of the President at any time prior to the framing of the Constitution of the Constituent Assembly, the Cabinet shall appoint as President a citizen of Bangladesh, who will hold the office of President until another President enters upon the office in accordance with the Constitution as framed by 
the Constituent Assembly, (e) There shall be a High Court of Bangladesh consisting of a Chief Justice and so many other judges as may be appointed from time to time, (f) The Chief Justice of the High Court of Bangladesh shall administer an oath of office to the President and the President shall administer an oath of office to the Prime Minister, other Ministers, Ministers of State and Deputy Ministers. The form of the oath shall be as prescribed by the Cabinet.

The Provisional Constitution of Bangladesh Order, 1972, was in pursuance of the proclamation of Independence Order of April 10, 1971 made by the then Acting President, Syed Nazrul Islam.

On the 14th of January 1972 Mujibur Rehman at a press conference gave the following policy statement:

\section{Policy Statement of Mujibur Rehman}

The following is the text of Sheikh Mujibur Rehman, Prime Minister of Bangladesh's statement at a news conference on 14th January 1972:

"Bangladesh has now taken its place as an independent, sovereign State in the world community. In order to attain this cherished goal, millions have had to lay down their lives and all sections of the people have undergone extreme suffering and made untold sacrifices. I recall with reverence the sacred memory of the millions of martyrs, who lost their lives and salute the heroes - young and old, peasants and workers, students and government servants, and in particular the brave sons of Bangladesh in the armed forces in the East Bengal Regiment, the former EPR, former Ansar, former Mujahids, police and all sections of the Mukti Bahini who united together to resist the oppressor."

"The savages of the Pakistan forces have left our country totally devastated. Systematic genocide has exterminated almost three million lives. Millions of homes have been burnt down. Entire villages have been wiped out. Among those that survived, millions were reduced to being refugees, having had to leave their homes in order to save their lives and the honour of their womenfolk. Those who remained behind have suffered inhuman tortures and may have had their property looted."

"As a result, the economy is in a shattered state. The most urgent task is that of reconstructing and restructuring the economy. The economy must be restored. Food, shelter and clothing must be provided. Educational institutions must once again function and education must be made accessible to all sections of the people. Relief and rehabilitation has to proceed on an emergency basis."

"Out of the ashes that have been left by the barbarous hordes of Yahya Khan, a new society must be built up from its very foundations. The people of Bangladesh had always aspired to establish on their soil a just society, free of exploitation. The Bengali people have had to pay very dearly in order to attain this aim. Having regard to our population, our resources and the basic economic realities with which we are confronted, it will be possible to fulfil the aspirations of the people by establishing a 
socialist economy. New planning machinery manned by the most competent professionals is undertaking the task of preparing a comprehensive blueprint for a new economy. Such a blueprint will involve institutional changes, in the fields of agriculture, industries and finance. These new institutions will seek to fully mobilise our material and human resources."

"They will further seek to maximise production, consistent with the aim of narrowing down social and economic inequalities. While such a blueprint is being prepared with the utmost speed and certain tasks are being undertaken on an emergency basis - the first is relief and rehabilitation for which a comprehensive plan has been drawn up."

"Mobilisation of resources from home and abroad must be immediately undertaken. We urgently need assistance from abroad to supplement our own resources for this purpose. I appeal to all States, to the freedom-loving people of the world and to the international humanitarian organisations generally, to come to our assistance in all spheres, including assistance in maintaining supply of essential commodities which are urgently required."

"I would like to express my gratitude and the gratitude of the people of Bangladesh to all freedom-loving States for their support, material and moral, in the national liberation struggle. I would like to record our special debt of gratitude to India, to Mrs. Indira Gandhi, Prime Minister of India, and her Government and her great people, for the total support extended by them to our struggle. I would similarly like to specially thank the Soviet Union and its great people for the consistent support extended by them to our cause, and for the invaluable role played by it in the United Nations. I would also like to express gratitude to Poland, Bulgaria and other East European countries, France and the U. K. I would also like to thank the freedom-loving people, journalists and leaders of thought and opinion throughout the world who supported our cause."

"I thank those States that have accorded recognition to us. India, Bhutan, the German Democratic Republic, Bulgaria, Poland, Mongolia, Burma and other nations. The Bengali people have consistently supported freedom struggles throughout the world in Asia, Africa and Latin America. I, therefore, expect States all over the world, specially those who have tried to struggle for their independence, to extend recognition to the People's Republic of Bangladesh and to support its membership in the U. N. As regards our relations with Pakistan, I expect Mr. Bhutto to accept the reality of independent, sovereign People's Republic of Bangladesh.”

"I expect that the People's Republic of China which itself had attained liberation by armed struggle against warlords, feudal and colonial exploiters, should recognise the heroic success of our national liberation struggle. I hope that the People's Republic of China will now come forward to recognise the reality of the independent sovereign People's Republic of Bangladesh so that a basis may be established for mutual cooperation."

"I am deeply concious of the fact that it is necessary to maintain a framework of law and order in order to enable the people to undertake the task of nation-building. It is but natural that those who have suffered from the cruelties of the Pakistan forces and their local collaborators are at the moment imbued with bitterness. Despite this, they have acted with 
commendable restraint. I would like to ass ure our people that those who are responsible for committing atrocities and for collaboration will not go unpunished. At the same time it should not be forgotten that one of the fundamental aims of our national liberation struggle was to establish the role of law and respect for fundamental human rights. The culprits will be duly punished in accordance with the due process of law. I would, therefore, appeal to all concerned to remain patient while the due process of law takes its course."

"I am taking immediate steps to ensure that the High Court and the subordinate courts begin to function. I would like to ensure that necessary steps are taken to correct some of the fundamental defects in the judicial system, with a view to elimination of corruption and delays. The principle of separation of the judiciary from the executive will be scrupulously observed."

"While we set about to tackle the urgent task of relief and rehabilitation and economic reconstruction, we shall not delay a single moment more than is absolutely necessary in convening the Constituent Assembly in order to place before it the draft constitution of the People's Republic of Bangladesh. The preparation of the draft constitution is already under way."

"The strength of a united and determined people has added a glorious chapter to the history of national liberation struggles. Today the same strength and power of the people must be mobilised in order to liberate our people from poverty, hunger, illiteracy, disease and every form of exploitation. I am confident that with the total support which the people have given to my party and to myself we shall overcome the enormous problems with which we are confronted, and that we will be able to lay down the foundations of a just society, free from exploitation, for the attainment of which so many millions have laid down their lives and countless others have borne untold sufferings."

A Constitution Committee was thereafter set up headed by the Law and Parliamentary Affairs Minister Dr. Kamal Hossain who was to submit the draft constitution to the Awami League Working Committee for its consideration before it was placed before the Constituent Assembly. The draft constitution was duly prepared, approved and placed before the Constituent Assembly.

\section{The Constitution of Bangladesh}

On the 4th of November 1972 the Constituent Assembly of Bangladesh finalised its constitution and thus came into existence the constitutional charter of the youngest nation in South East Asia. After a violent and bloody struggle for independence was enshrined in a document the dreams and ambitions of a proud people. The salient features of the Constitution of Bangladesh are noted below.

\section{Resolution adopting the Constitution}

The resolution of the Constituent Assembly adopting the Constitution of Bangladesh may be summarised as follows: 
"We the people of Bangladesh have declared our independence on the 26th of March 1971 and for the liberation of the nation we have raged a historic war and have established an independent and sovereign People's Republic of Bangladesh. We promise that the ideology which inspired our freedom fighters and heroic martyrs to sacrifice their lives, viz., nationalism, socialism, democracy and secularism, these ideals shall be the main features of our Constitution. We further promise that the main objectives of our nation shall be to establish by democratic methods a socialist society free from exploitation of any kind which will ensure for every citizen the rule of law, basic human rights and political, economic and social equality, liberty and justice. We firmly declare that in order that we can prosper in independence and keep pace with the progress, hopes and aspirations of humanity and in order to enable us to advance the cause of international peace and cooperation and to play our full and rightful part therein it is our pious duty to keep the supremacy of this Constitution which is the expression of the will of the people of Bangladesh and the preservation, support and security and maintenance of the Constitution is our noble duty. We in our Constituent Assembly, on the 4th of November 1972, adopt, finalise and accept this Constitution of Bangladesh."

\section{Text of the Constitution}

The Constitution of Bangladesh consists of 11 Chapters and 4 Schedules. The chapters and schedules are as follows.

Chapter I. This chapter consists of 7 articles and provides for the republic, boundaries, the national language, the national song, the national flag and emblem, the capital, citizenship and supremacy of the Constitution. Bengali is the national language of Bangladesh and the Constitution is in Bengali language. The name of the State is People's Republic of Bangladesh (Gana Prajatantri Bangladesh). The capital of the State is Dacca.

Chapter II. This chapter consists of provisions which are the directive principles of the administration of the State. This is contained in articles 8 to 25. These articles deal with the directive principles, viz., nationalism socialism and freedom from the exploitation, democracy and human rights, secularism and freedom to practise religion, principles of ownership, liberation of farmers and labourers, development of villages and agricultural revolution, free and compulsory education, public health and morality, equality of opportunities, rights and obligations, duties of citizens and Government officials, separation of judiciary from the executive, national culture and heritage, national museums, international peace, security and cooperation and the development thereof.

Chapter III. consists of fundamental rights. This chapter is composed of articles 26 to 47. This chapter deals with abrogation of laws not in conformity with fundamental rights (article 26), equality in the eye of law (article 27), elimination of discrimination on the ground of religion, etc. (article 28), equality of 
opportunities in getting state employment (article 29), abolition of titles, honours and decorations (article 30), right to obtain protection of law and legal processes (article 31), security of life and property (article 32), safeguard against arrest and detention (article 33), elimination of compulsory labour (article 34), assuring justice and punishment in proper cases (article 35), freedom of movement and of meetings and freedom of thought, conscience and expressions (articles 36 to 40), freedom to practise trade, avocation or vocation (article 40), religious freedom (article 41), freedom to own properties (article 42), security of homes and rights of privacy (article 43), enforcement of fundamental rights (article 44) and powers of State to enact laws by changing certain rights (articles 45 to 47 ).

Chapter IV consists and provides for the Executive. This chapter is contaned in articles 48 to 74 . This chapter has five parts. First part deals with the President (Rastrapati), his powers, his rights of exercising clemency, tenure of the office of the President, impeachment of the President and appointment of the Speaker to function in the office of the President during temporary absence of the President (articles 48 to 54). Second part is contained in articles 55 to 58 and provides for the Prime Minister and the Cabinet. It provides also for the tenure of the office of the Prime Minister and other Ministers. Third part deals with the local-self Government and is contained in articles 59 and 60. The fourth part consists of provisions for the administration of defence and provides for the Commanderin-Chief, other officers and of war and is contained in articles 61 to 63 . The fifth part consisting of only one article, article 64, provides for the office of the Attorney General.

Chapter V deals with the legislature. This chapter is contained in articles 65 to 93. This chapter is divided into three parts, viz., legislature and parliament in part 1, legislation of laws and financial rules in part 2 and powers of passing ordinances in part 3. Part 1 contained in articles 65 to 79 provides for establishment of the parliament (Sangsad), qualifications and disqualifications for becoming members of the parliament, vacation of offices of members of the parliament, the salaries and emoluments of members of the parliament (article 68), provisions for taking oath (article 69), vacation of offices of members of parliament on resigning from political parties or in case of voting against the mandate of the party (article 70), sessions of the parliament (article 72), the address of the President (article 73), Speaker and Deputy Speaker (article 74), rules of work, quorum and permanent committees of the parliament (articles 75 and 76), Nayapal (Ombudsman) (article 77), special rights and privileges of the parliament and members thereof (article 78), secretariat of the parliament (article 79). Part 2 of this chapter dealing with promulgation of laws and financial rules is contained in articles 80 to 92 . This deals and provides for procedure of enacting laws (article 80), money bills (article 81), prevention of imposition of taxation without sanction of the parliament (article 83), consolidated funds and accounts (article 84), control of currency (article 85), powers of the State to distribute funds (article 86), annual accounts (article 87), charge on consolidated funds (article 88), provisions for allocation, etc. (article 91), accounts, loans and votes thereon (article 92). Part 3 consists only of one article, article 93 and provides for ordinance making powers. 
Chapter VI provides for the judiciary. This chapter is contained in articles 94 to 117 and has three parts. Part 1 (articles 94 to 113) provides for the Supreme Court and establishment thereof, appointment of judges of the Supreme Court, tenure of such judges, appointment of additional judges, disabilities of jedges of the Supreme Court.after retirement, jurisdiction of the High Court and powers of the High Court to issue writs, orders and directions for enforcement of fundamental rights, appellate powers of the High Court, advisory powers of the Supreme Court, powers of the Supreme Court as a court of record and its supervisory powers on other subordinate courts, etc. Part 2 contained in articles 114 to 116 makes provisions for the subordinate judiciary. Part 3 provides for establishment of administrative tribunals (article 117). A judge of the Supreme Court can only be removed from his office by an order of the President passed with support of a resolution of the Parliament having a two-thirds majority of members of the Parliament [article 96 (2)].

Chapter VII (articles 108 to 126) provides for election. This chapter provides for an Election Commission and Election Commissioner. The Election Commissioner is appointed by the President and holds his office for a tenure of 5 years. Election Commissioner is not removeable from his office excepting in the same manner as the removal of a judge of the Supreme Court. In article 122 the franchise is also fixed. A citizen of Bangladesh over the age of 18 years and of sound mind is entitled to exercise his franchise and vote at the elections.

Chapter VIII (articles 127 to 132) provides for Auditor General and Comptroller. The Auditor General is not removeable excepting in the same manner as a Supreme Court judge. The Auditor General holds office up to the age of 60. The Auditor General has to make a report to the President and the President is to place it before the parliament.

Chapter IX (articles 133 to 141) provides for the Executive of Bangladesh. This chapter is divided into two parts. Part 1 deals with the terms of appointment of civil servants, their tenure of service and provides safeguards against removal or demotion. Part 2 provides for a Public Service Commission. Members of the Commission are appointed by the President. Article 140 deals with the responsibilities of the Commission. The Commission has to make an annual report to the President and the President arranges for its being placed before the parliament.

Chapter X (article 142) provides for amendment of the Constitution. Under this article the Constitution can be amended only by a two-thirds majority of the parliament. An amendment passed by a requisite majority has to be placed before the President for his consent and if the President fails to give his consent within seven days then at the expiration of such time the President will be deemed to have given his consent to the same.

Chapter XI (articles 143 to 153) makes provisions for miscellaneous matters. Article 143 provides that all underground mineral rights as also rights within the territorial waters and the continental shelf are the property of the nation. Article 145 provides that all treaties and documents have to be expressed in the 
name of the President of Bangladesh. Article 146 provides that suits and proceedings can be instituted against the Government of Bangladesh. Article 147 makes provisions for fixing the remuneration and emoluments of various holders of public offices including the President, the Prime Minister, Speaker and Deputy Speakers, Ministers, Judges of the Supreme Court, Accountant General and Comptroller, Election Commissioner and Members of the Public Service Commission. Other miscellaneous matters are dealt with in this chapter.

There are four schedules to the Constitution. Schedule I provides for validation of certain laws. Various existing statutes and orders are validated specifically under this schedule. Schedule II provides for certain details as to the election of the President. President is elected by members of the parliament. The Chief Election Commissioner is entrusted with conduct of this election. Schedule III provides for and fixes the constitutional forms of the oaths to be administered to the President, the Ministers, Speaker and Deputy Speakers and members of parliament. It also provides for the oaths and declarations of various persons including the Chief Justice and other judges, the Chief Election Commissioner and Auditor General and Comptroller and members of the Public Service Commission. Schedule IV makes provisions for legislations and temporary rules and laws. It makes various provisions for and validates actions taken before the Constitution came into existence.

\section{Salient Features of the Constitution of Bangladesh Directive Principles}

Directive principles embodied in the Constitution provide the keynote to the nature of the Constitution. The four most important elements embodied in this chapter are that the directive principles of the Constitution are based on the principles of nationalism, socialism, democracy and secularism. The war of liberation of Bangladesh was based on the aspiration of the Bengali people to get their independence. Bengalee nationalism has been made one of the directive principles of the Constitution. Bengali is the State language and the Constitution is written in Bengali language. The Constitution further provides that the object of the Constitution is to establish a socialist society based on justice. The establishment of a democratic government and assurance of basic human rights and liberties is also made one of the directive principles of the Constitution. One of the most important features of the directive principles is secularism and freedom of all citizens to practise their religion. It also provides that all types of communalism have to be eradicated. The Constitution forbids making of any religion as a state religion, using religion for political purposes and provides for abolition of discrimination against any person on the grounds of religion. As the Constitution of Pakistan has provided for making Islam the state religion this has been one of the most important departures from religion-based and non-secular constitutions. The above principles which have been made parts of the directive principles were enunciated by the Prime Minister Mujibur Rehman at the time of his struggle for independence. $\mathrm{He}$ thereby clearly substituted modernism for medievalism. The directive principles ensure that Bangladesh continues in a proper path for its 
development as one of the modern secular democracies of the world. The chapter on directive principles makes various other interesting provisions. Article 13 provides for stateownership of all major fields. It also provides for cooperative ownership of property within the limits of law. It is clearly indicated that the rights of individual ownership can be limited or abridged by the State from time to time. Under article 14 it is one of the objects and responsibilities of the State that all labouring men, farmers and labourers are to be liberated from all forms of exploitation. Under article 15 one of the basic objects and responsibilities of the State is to have planned economic progress and material and cultural advancement of the citizen. It specifically provides that the State is to take steps for providing food, clothing, shelter and economic assistance of citizens and recognises right to work and reasonable remuneration for the same, adequate rest, relaxation and holidays, and social security. The State is directed to take steps to eradicate unemployment, sickness and any economic difficulties arising out of sickness, widowhood, old age, etc. Principles of a modern welfare state are thereby entrenched in the Constitution. Article 16 also provides for elimination of differences between urban life and rural life. It specifically provides for development of villages, electrification, cottage industries, etc. In the background of the difficulties experienced by various countries by rapid urbanisation and growth of megalopolis this is an important provision. Subsequent actions of the Bangladesh Government also show that the Government is taking active steps to implement these directive principles. Article 17 provides for free and compulsory education for all up to standards fixed by the State. Article 19 and 20 embody certain principles of socialism. Article 19 provides for equality of opportunities as also eradication of inequalities. Article 20 provides that for every ablebodied citizen work is a right, duty and an honour. It further incorporates the principle "from everyone according to his capacity and to everyone according to his work". It is interesting to note that the expression used here is that to everyone according to his "work" and not according to his "needs". It has been interpreted by some that the obligation of citizen to work conscientiously and the linking up of remuneration to work may have an effective bearing on movements for voluntary ceasing of work for political purposes. Article 25 puts also in the directive principles some of the international obligations of the State. Principles of sovereignty and honouring the concept of equality of States, non-interference in the international affairs of other States, peaceful settlement of international disputes, honouring international law and the charter of the United Nations are specifically provided for in article 25 . This article also accepts as principles avoidance of use of force in international affairs, disarmament, co-existence and rights of every state to govern its affairs according to its own social, economic and political views, and elimination of imperialism, colonialism and discrimination on the ground of colour or complexion and pledges support to the oppressed people of the world in their struggle against such discriminations.

\section{Fundamental Rights}

The chapter on fundamental rights gives constitutional recognition and entrenches in the Constitution various human rights. It provides for total elimination of 
any discrimination on grounds of religion, community, colour, sex or birth of any citizens. It however provides for power to the State to make laws for protection or advancement of women and children and also for advancement of any backward communities. This chapter also provides for assuring liberty of the people and provides that excepting by the due process of law no person can be deprived of his life or personal liberties. No one can be arrested without informing him of the cause of arrest and every arrested person must be given facilities for consulting his own lawyer and defending himself. Every arrested person must be produced before a court of law within 24 hours and cannot be detained beyond 24 hours without an order of court. Under article 36 freedom of movement is ensured as a fundamental right. It is interesting to note that this freedom is not confined only to movement within the territory of Bangladesh but it also ensures to citizen the right to leave Bangladesh and re-enter the same. The chapter also provides for freedom of association, of meetings and of thought and expression. Freedom of press is also specifically provided for in article 39. It is interesting to note that in spite of accepting socialism as one of the basic principles article 42 clearly provides for right to own properties and to transfer the same. The State's power to nationalise private properties is preserved but compensation has to be given for the same. It is however specifically provided that no such action of the Government can be challenged in court on the basis that the compensation is not adequate. This clause is expected to avoid a lot of the controversy which arose in India on the ground that compensations offered by the State were not adequate or not a just equivalent of the properties taken. Article 44 provides that action can be instituted directly in the Supreme Court for enforcing any of the fundamental rights.

One of the controversies which may arise later is the right of the Parliament to amend the fundamental rights. This point had raised a nationwide controversy in India and was the cause of a constitutional storm. If the constitutional rights are considered to be human rights entrenched in the Constitution then they are not alienable rights nor has the Parliament the right to amend such provisions within the powers granted to it for amendment of the Constitution. It may be open to question whether in such a case a Constituent Assembly has to be re-convened for the purpose of considering such modifications.

\section{Parliament and Government}

Bangladesh under its Constitution is a parliamentary democracy with the Cabinet form of government. The President is the head of the State but the power of government lies with the Prime Minister. The Prime Minister selects his Council of Ministers. The Constitution provides for collective responsibility of the Cabinet and the Cabinet is responsible to the parliament. The Constitution provides for universal adult franchise, every person of sound mind and over the age of 18 being entitled to vote. The parliament is unicameral and there is parliamentary supremacy within the limits fixed by the written Constitution. The Constitution itself provides for parliament's power of amending the Constitution. 


\section{Supreme Court and High Court}

The Supreme Court is under the Constitution the guardian of constitutional rights. In case of any violation of fundamental or constitutional rights action can be taken in the High Court or Supreme Court. The Supreme Court also has advisory jurisdiction and the President may refer any question to the Supreme Court for advice. There is total separation of the executive from the judiciary. The Chief Justice and Judges of the Supreme Court and High Court are appointed by the President and are not elective offices. The Judges hold office till the age of 62 and are not removeable except by an order of the President passed on the basis of a resolution of the parliament with two-thirds majority. 


\title{
The Art of Constitution-Making
}

\section{By Herbert KrüGer}

In 1973 a commission preparing a total revision of the Swiss Federal Constitution published a report („Wahlen-Bericht"). The first part of this report, which deals with the conditions for a total revision of the Federal Constitution, could be called an instruction for constitution-making. The pattern of constitution-making has first of all to deal with the mode of procedure. But for lack of material the author is not able to draw any generalisation in this field. Therefore he attempts to show how the rightness of the contents of a constitution may be achieved. This depends on the situation in which constitution-making is attempted. Two main situations are distinguished, the ending of a revolution and constitutional change in an undisturbed state. After a revolution, the constitution has to establish a political order and to build a nation, whereas in the latter case continuity must be regarded as a high priority.

The constitution is shaped by the ideas of the constitution-maker and his perception of the realities of his country. It seems that a good constitution has to rely more on the social reality than on ideologies. Therefore it is necessary, that the constitution-maker analyzes the concrete situation of his state. The constitution however should not be a transformation of the reality into norms only, but should also achieve a better society. It is clear, that a constitution-maker will generally fail, if he is guided by mistrust and pessimism. The two main features of a constitution are: a programme of national integration and a programme of national

representation. Integration means the building of a nation by integration of the individuals as citizens into the state. A constitution has to provide the possibilities for this process, namely the symbols of integration and the freedoms, which are necessary to perform the role of a citizen. Representation means that the citizens must form a collective will, for only collective efforts can satisfy the great needs in our times. The constitution has to provide also for the formulation of a common will and a procedure, which guarantees that not any will but the best or at least the better will may prevail. Finally the constitution has to be a national authority in order to prohibit its destruction. This is the most difficult task of constitutionmaking. A constitution can gain the necessary authority if it relies not on private ideals but on cosmopolitan ideals of the highest standard.

\section{The Constitution of Bangladesh and a Short Constitutional History}

\author{
By S. C. SEN
}

After the withdrawal of the British from the Indian Empire Bengal found itself as part of Pakistan, but the only link with West-Pakistan (1200 miles away) was religion. In 23 years of joint history the East was denied almost all rights. With the six-point formula of Bengal autonomy Sheikh Mujibur Rehman gained an enormous victory in the 1970 election to the proposed National Assembly. Fearing majorisation by the East the party leaders of the West secured the postponement of the meeting of the National Assembly by President Yaya Khan. Over a campaign of non-cooperation answered by a reign of terror, this led to the Declaration of Independence and the civil war. 
By the Provisional Constitution Order a Parliamentary System was set up. The Parliament consisted of the members elected to the National Assembly and acted also as Constituent Assembly. It approved the Constitution on the 4th of November 1972. The main features of the Constituion are a chapter on principles of State policy which are based on four elements, namely nationalism, socialism, democracy and secularism. Fundamental rights are guaranteed including the right of property. Bangladesh is a parliamentary democracy with a Cabinet form of government. The Parliament is unicameral. The Constitution provides also an independent judiciary as guardian of the constitutional rights.

\section{Populism in Colombia: The ANAPO}

\section{By W. Wessel-Schulze}

Since independence there have been two dominant parties in Colombia: the Conservatives and the Liberals. For centuries each of them has governed the country until 1948. The following party strife, called the "violencia", has been one of the most violent and brutalized struggles of the twentieth century. At the brink of civil war and absolute chaos the military under the leadership of General Rojas Pinilla took over power. Being ousted by his colleagues in 1957 a military junta governed until August 1958. The party coalition of Conservatives and Liberals, called the "National Front", brought political stability with a system of parity and alternation. That meant equal share of all governmental offices and a change of the presidency between the two parties for sixteen years.

Having returned from exile Rojas Pinilla looked for supporters of a populist policy in the parties. Between 1960-1970 Rojas and his daughter, Maria Eugenia, were successful in building a mass party. In the 1970 presidential and governmental elections the so called ANAPO lacked only 65000 votes. In 1971 the ANAPO was officailly founded in the historic province city of Villa de Leyva.

The ANAPO has often been called a "populist party". according to Torcuato Di Tella the main elements of a populist movement or party are: a) a broad mass basis, b) an elite often dominated by a charismatic leader, c) a vague ideology. The mass basis of the ANAPO is recruited from the marginal population of the big cities. In the elections of 1970 the ANAPO received 60 to 65 per cent of all votes of the lower classes. In the leadership are men from the middle and upper classes. At its top stood Rojas Pinilla as the charismatic leader until 1972. Now his daughter holds this position. In the ideology, written down in the "plataforma", the dispossessed people are promised everything from land to free education. On the other hand capital or property of the upper class will not be nationalized, class-struggle is not forced.

In the elections of the province parliaments in 1972 the ANAPO has lost half of all votes compared with those won in the elections of 1970. In the presidential elections in April 1974 the ANAPO candidate, Maria Eugenia Rojas de Moreno, was the third with not more than 450000 votes. After this enormous loss of votes, especially in the lower classes, the fate of the ANAPO is unsecure. Surely it is not a competing third mass party any longer. 